\title{
COMMUNITY AND FAN TRANSLATION: POTENTIALS FOR NEW DIRECTIONS IN TRANSLATION STUDIES IN THE DIGITAL SPACE
}

The aim of this paper is to present two relatively new trends in Translation Studies in the digital space and to present some of the interdisciplinary implications new directions might have in Translation Studies in the future. Not only does the digital space provide new tools and technologies, but it also enables the investigation of phenomena and practices beyond existing interdisciplinary relationships that Translation Studies has established so far. In this paper we shall present the relatively new trends of community translation and fan translation with the aim to draw attention to the necessity to investigate these two forms of translation further as they may be beneficial to all stakeholders in translation, i.e. researchers, practitioners, trainees and representatives in the translation industry at large. The final presentation of the potential implications of new interdisciplinary directions might motivate theoretical investigations of Translation Studies in the digital space that may have been underestimated so far with the outcome to open a door to the application of community and fan translation in a context beyond the entertainment industry where they currently occur.

Keywords: Translation Studies, digital space, community and fan translation, interdisciplinarity, implications

\section{Introduction}

Quite a large pool of research is available in the literature regarding the moment when Translation Studies (TS) was established (cf. BAKER \& SALDANHA 2009; SNELL-HORNBY, 2006). There is also substantial evi-

\section{1 jasmina.djordjevic@filfak.ni.ac.rs}

2 The paper is a result of the project Teaching Language for Specific Purposes: Challenges in the Social Sciences and the Humanities, financed by the Faculty of Philosophy, University of Niš, Serbia (2019-2020). This study was supported by the Ministry of Education, Science and Technological Development of the Republic of Serbia (Contract No. 451-03-9/202114/200165). 
dence referring to the reasons why TS is an interdisciplinary field of research (cf. BASSNETT 2013; TOURY 2012). Among other major contributions to TS, Holmes' insisting (1988) on the cooperation between translation theorists and practising translators, as well as between different scholars and schools, provided TS with necessary arguments to engage in interdisciplinary studies. With the new millennium well under way, new trends in the discipline of TS are appearing and novel interdisciplinary directions are being discovered (OŽBOT 2015). At a time when the digital space is taking primacy over the non-digital one in many scientific disciplines, TS is expressing both a strong tendency and a general need for interdisciplinary research within the digital space as well.

Within some of the interdisciplinary directions that TS has taken up to now, various relationships have been established, such as to cultural studies (KATAN 2014; ROSMAN \& RUBEL 2003), cognitive linguistics (ROJO 2015), psycholinguistics (HEJWOWSKI 2004), to name a few. A new trend can also be seen in investigations of discourse in TS (SCHÄFFNER 2019; MUNDAY \& ZHANG 2017). As stated by Munday and Zhang (2017), discourse analytic approaches are a significant aspect of translator training and translation analysis but seem to have been neglected in TS. Another new interdisciplinary approach is Critical Translation Studies (CTS), a cultural-studies approach to the study of translation (ROBINSON 2017). Identifying translation as a social practice, CTS approaches translation as being shaped by power relations in society and it is dedicated to the historicization of the social relations that create a scenario of two separate languages with the translator functioning as a mediator. Within each of the interdisciplinary relationships mentioned here, TS has contributed by providing new approaches to phenomena investigated within the respective disciplines.

Nevertheless, it appears that TS is unable to move away from traditional debates about source or target orientations in translation, dynamic or formal equivalence, semantic or communicative translation, foreignization or domestication, etc. (CRONIN 2010). All these debates focus on the notion of the agent - the translator - who produces content in a target language for an audience - the recipient. This model cannot be discarded altogether, because it is what translation is about. However, the digital space which is based on the bidirectionality of Web 2.0 presupposes that translation can take new directions - moving not only from the translator to the recipient, but the other way around as well, or as will be presented here, even from recipient to recipient (GAMBIER 2016).

Despite the rise of various new trends in translation services and in practical applications of translation as a profession, it seems that the industry of translation and the study of translation do not always move in the same 
direction (DAM \& KOSKINEN 2016). That is why this theoretical research is aimed at presenting directions that TS might take within the context of recent advances in the digital space. The paper will first focus on translation in the digital space in general and then provide details about community and fan translation as two relatively new trends in translation. In the final section, the paper will present some interdisciplinary implications that new directions might have in TS in the future by referring to objectives which may be grouped into three categories: a) theoretical research, b) translator training and c) professional practice.

\section{Translation in the digital space}

During the last two decades, the most extraordinary development related to the digital space is the shift from stand-alone PCs (a fixed work station) to distributed computing (via portable laptops, PDAs, mobile phones, etc.). In addition, accessibility to the Internet almost everywhere has brought about the shift to ubiquitous computing "where associations between people, place/space and time are embedded within a systemic relationship between a person and their kinetic environment" (DENNIS \& URRY 2007: 13). Consequently, translation as a necessary activity in a multilingual information-immersive environment is now attributed new roles as it is part of a networked system (DOHERTY 2016). Instead of content being provided in the form of separate language information, it is now personalized and part of different language and culture systems of ubiquitous delivery. This means that such content is no longer confined to one space, it is accessible and transferrable, i.e. it may be translated by anybody with just a few clicks and presented within only a few minutes (if not seconds) to audiences in every corner of the world (2016).

Such development is not without criticism primarily due to the fact that translations provided by non-professionals are often of questionable quality (ŠVELCH 2013). This is probably an area where TS could offer scientifically proven and methodologically grounded solutions to the otherwise conspicuous realm of ubiquitously driven translation based on collaborative work performed by volunteers (O'HAGAN 2011). Examples of community-driven translations (Second Life, Facebook, Wikipedia, etc.) do bear remarkable value considering the amount of information that is now available across and beyond both linguistically and culturally constrained space (HENRY 2019; O'HAGAN 2017). However, the rapid dissemination of online networking practices has resulted in the fact that translation consumers are de facto translation producers, i.e. they are gladly accepted volunteers whose enthusiasm and devotion to online content drives them into becoming active participators in the dissemination of information within the global multilingual and multicultural network (DOHERTY 2016). 
Given that the interactive web has brought about new media which necessarily reshape the role of translation, such new roles need re-evaluation. Online newspaper outlets, social networks, discussion forums, collaboration platforms, etc. are now a maze of hyperlinks and searchable chunks which generate content that is intertwined and connected to other content sources (CARR 2011). The translation of such content needs a particular approach (DOHERTY 2016). As will be presented in the next section, two solutions that have literally imposed themselves are community translation and fan translation. These relatively new types of translation shift the focus from the professional translator to a completely new agent - the audience. Both community and fan translation are consumer-oriented models where the audience is producing their own content in various languages (O'HAGAN 2017) so that it seems that the traditional model with active translation agents on one side and passive or unknowable translation recipients on the other side is losing its primacy.

Another very important aspect of the new media is that audiences evolve in terms of their reading practices. The Internet practically imposes that readers switch to browsing instead of reading (HAYLES 2010). The ordered and linear progression through a text is now turning into quick clicking and jumping from one content to another. Identified as hyperreading, this new type of reading habit "enables a reader quickly to construct landscapes of associated research fields and subfields; it shows ranges of possibilities; it identifies texts and passages most relevant to a given query; and it easily juxtaposes many different texts and passages" (HAYLES 2010: 66). What seems inevitable is that translation, both as an industry and as a theory, should consider following this accelerated browsing practice and that translation pedagogy should consider offering adequate training to future translators who will have to accommodate audiences at a completely different level of literacy.

\section{Interdisciplinary directions in translation studies in the digital space}

In many areas of communication, translation included, investigators now consider the presentation of information in forms such as photographs, diagrams, graphics, icons and so on in combination with linguistically presented information (BATEMAN, WILDFEUER et al. 2017; BORIA, CARRERES et al. 2020). Relying on that idea, two very potential practical fields to be explored in TS suggested here are community translation and fan translation. Both are forms of crowd translation, a field in TS largely investigated both as a positive and a negative trend (HENRY 2019; JIMÉNEZ-CRESPO 2017; O'HAGAN 2017).

Crowd translation, as an umbrella term for community and fan trans- 
lation, is an approach where multiple individuals are working on a text simultaneously and it is a direct result of media users extending their involvement in media by forming a participatory culture (JENKINS 2006). The term that underlies this new concept is "user-generated content" (UGC) as it implies "the way in which users as both remediators and direct producers of new media content engage in new forms of large-scale participation in the digital media spaces" (FLEW 2008: 35-36). In other words, freely available and accessible content on the Internet is not only used by audiences - it is changed, modified and even translated by them as well. In translation, large projects are broken down into segments and distributed to bi/multilinguals who need not necessarily be professional translators which is why it may be referred to as "user-generated translation", a term suggested by O'Hagan (2009) drawing on Flew's description of UGC.

Traditionally, companies employ a translation agency whose project managers work with individual translators. With crowd translation, community and fan translation included, there usually is no agency and there might be no project manager. There is mostly an online platform accessed by freelance translators who simply work together. The main benefits are that less money is spent on high translation fees usually requested by professional translators and projects progress more quickly. The potentials of this approach are that professional translators or bi/multilinguals with solid language knowledge may resort to platforms enabling them to offer their translation services within crowd translation projects. Teams of native-speaker translators can be set up to handle large localization and translation projects. A project can easily be divided among the team members providing thus localized or translated products for video production, multilingual advertising or other company-specific material to be presented to multilingual and multicultural audiences.

Community and fan translation are related to specific crowds and/or audiences which is why they may be considered two separate types of crowd translation.

\subsection{Community translation}

The most prominent feature of the digital media is that they offer "important opportunities to deliver traditional, linear information and media experiences in new ways" (FELDMAN 2005: 13). The unique value added to such experience is "not in the inherent character of the product so much as the manner in which it reaches its customer" (2005: 13). This new manner is characterized by interactivity which "gives the user some influence over access to the information and a degree of control over the outcomes of using the system" $(2005,14)$. The interactivity is most often realized within a specific cyberspace 
community which is characterized by its own structure, dynamics, interpersonal relationships, social impact, etc. (WELLMAN 2018). Online groups and communities are commonly seen on social networks, such as Facebook, Instagram, TikTok or Snapchat but also on cross-platform voice over Internet protocol (VoIP) and instant messaging (IM) software applications such as, Messenger, Viber and WhatsUp. In all these communities, translation happens whenever some content needs to be transferred to members of a different language and culture group within those communities (O’HAGAN 2017).

Based on the fact that community translation relies on UGC and that it is performed by self-selected individuals who voluntarily translate, this type of translation is similar to crowd translation (O'HAGAN 2011). However, the significant difference lies in the fact that in community translation individuals already share common interests and the common space of the community they belong to. Such communities are quite common in the field of game localization where the gamers are not only committed players of the games but they are also the ones who have "amassed the necessary knowledge to undertake the often technically intricate task of game localization" (O'HAGAN 2009: 97). In other words, they know the game, they have the connections to other players; therefore, they are the perfect translators and localizers. Even professional translators are unable to deliver translations within a community as accurate as the translation provided by the users themselves.

For instance, social networking companies and large multimedia companies encourage users of social networks and various online communities to volunteer and aid the localization and translation of online content. This means that every user of a social network can be a translator. Large companies, such as Facebook, have their community of translators who provide translations of the content on the network. They are referred to as the Translate Facebook Team who invites their members to translate Facebook into various languages.

However, a more important aspect to be acknowledged is that social networking platforms (or rather the companies behind them) recognize and make ample use of the innate need of human beings to socialize and interact which will aid the process of performing tasks in different professional areas, including translation (O'HAGAN 2017). Of course, large companies who are relying on their community for proposed translations, Facebook being one of them, also employ professional translators to maintain quality so that community translation settings are not entirely dependent upon untrained volunteers (O’HAGAN 2011).

\subsection{Fan translation}

An outstanding feature of the World Wide Web is that it enables 
connectivity of massive proportions. People who share ideas and have similar inclinations are no longer restricted to the space of their own real-world community. They can connect, congregate and work together in their virtual communities (as defined by RHEINGOLD 1993) within which volunteer networks are being created who initiate actions, perform tasks, raise awareness and mediate between and among users or even build translator networks (PORRAS \& CASSANY 2017; O'HAGAN 2017). If such network is driven by the enthusiasm of its members to help the dissemination of specific content, such as instructions, details about a product/person/activity/etc. or approach to a procedure, the translator network may be defined as a fan translation network (SAURO 2017). It is similar to community translation since it is built by a community of fans who no longer are passive spectators but are both active producers and consumers of products identified by Tapscott and Williams (2006) as "prosumers". In other words, "potential consumers of translations double as translation producers” (O’HAGAN 2009: 99).

Fan translation is mostly but not exclusively related to the translation of video games, webtoons and other multimedia content where players, viewers and users supply suggestions for the translation of the content (O'HAGAN 2009). Members of fan translation communities rely on open-source software and they are highly coordinated even without a project manager or translation agency dispatching translation jobs to professional translators. What is more, fan translators are extremely motivated individuals driven by an inherent wish to advocate the general spirit of free sharing and using online content. A rather early form of fan translation may be recognized in fan-produced subtitles for anime referred to as fansubs which are a type of user-generated translation produced by fans for fans (DÍAZ-CINTAS \& MUÑOS SÁNCHEZ 2006).

A drawback of both community and fan translation is that they raise concerns related to the quality of the final product, i.e. the translation because many people work on smaller segments of a larger text (O'HAGAN 2015; ŠVELCH 2013). Important text features, such as coherence and cohesion may be corrupted which means that additional work has to be put into the reviewing and editing such translation (ŠVELCH 2013). Most often, there is no post-production, no post-editing nor is there a quality check. In addition, these types of translations are unofficial and they are most often handled by amateurs who may lack important knowledge of translation techniques and strategies. Nevertheless, such translations are authentic and they are provided by members of the audience who the translation is directed at (O'HAGAN 2009). Thus many elements specifically related to certain cultures and subcultures are translated accurately, a quality which may not be guaranteed by professional translators who are not part of the culture or subculture. 
4. Directions for the future

Although community and fan translation in the digital space are burdened by two major issues, that of copyright (MOORKENS 2016) and quality (ŠVELCH 2013), the implications for their integration in TS are numerous. Given that the aim and scope of this article were not meant to elaborate on the problems of copyright and quality within translation in the digital space, this section will be devoted to the potential implications of TS in relationship to interdisciplinary possibilities arising from translation practices performed in collaborative user-generated settings, i.e. the digital space, as these should be given more attention in future TS research. Nevertheless, the problems of copyright and quality are not underestimated at all which is why they need to be the subject matter of some future, more elaborate research.

The implications of research linking TS to the digital space and taking it into new interdisciplinary directions should be motivated by several objectives which may be grouped into three categories: a) theoretical research, b) translator training and c) professional practice.

Given the criticism directed at the lack of quality in community and fan translation (ŠVELCH 2013), TS should explore possibilities to ensure consistency, cohesion and coherence of the segments shared by translators in crowd-sourced translation in general. Considerable knowledge may be drawn from the field of discourse studies (SCHÄFFNER 2019), from general language studies focusing on the skill of writing (MATSUDA \& SILVA 2014) as well as multimodal discourse analysis (BORIA, CARRERES et al. 2020) to establish a system of analysis pertaining to the discourse in the digital space. In addition, analytical tools and models should be developed to enable the focus on specific cultural, cognitive, traditional and linguistic characteristics in both source and target texts to aid translators in the digital space to transfer these characteristics from one language into another. To achieve that, TS may rely on the Theory of Cultural Linguistics (SHARIFIAN 2017) which itself has drawn on many disciplines and subdisciplines to develop its theoretical basis (cognitive psychology, complexity science, distributed cognition, anthropology, critical applied linguistics, intercultural communication, intercultural pragmatics, etc.). It explores the relationship between language and cultural conceptualization and it offers a theoretical and analytical framework for investigating the cultural conceptualizations that underlie the use of human languages. All these issues, as well as many others, would inevitably lead to much better quality of translation projects currently completed as crowd-sourced translations in the digital space.

The second important interdisciplinary direction that TS should take in relationship to the digital space is the training of translators for this area. In 
other words, the methodology of teaching translation should include specific training regarding the translation of discourse on the Internet. Already in 2005, Tennent suggested that TS needs

"to keep abreast of technological changes, changes which affect the social fabric of the present generation and which will determine to a large measure the conditions under which the translator and interpreter work. New technologies, especially the Internet, offer unparalleled access to information, data banks and terminology that will facilitate the translator's work, provided he or she acquires the know-how to rapidly retrieve and assimilate them" (TENNENT 2005: XXI).

This means that TS should be involved in the development of curricula and/or syllabi focusing on modern approaches to the translation of content other than literary and non-literary texts in the traditional sense (e.g. web content in its broadest sense, video games, webtoons, cartoons, online commercials, banners, pop-ups, etc.). Translation courses should be designed to focus on providing students with skills and competences related to working with other translators in a crowd or community. Translation students should also be trained to analyse, understand and translate online and offline content from a wide range of products of modern culture.

The third, yet not unimportant aspect of new research in TS should be related to the practice of translation on the market (JIMÉNEZ-CRESPO 2013; KUSHNER 2013). Apart from establishing a clear legal framework for copyright issues (MOORKENS 2016), the objectives of TS within the practical application of translation in the industry itself should be to explore the possibilities of providing a framework of techniques and methods to facilitate the practical aspects of translation of content in the digital space in the future. In addition, TS should initiate and facilitate the implementation of quality standards and regulations for crowd-sourced, community and fan translations. Last but not least, TS should participate in the development of a system of evaluating and certifying bi/multilingual translators within networks of professional and/or amateur translators so that localization companies could resort to them for quality translation.

At this moment, translation as a profession exists within a language market that is burdened by various economic indicators both at a macro and a micro level (ELIA 2019). The list is long because numerous issues encumber the modern translation industry. To name a few, translation agencies have to accommodate to new market demands primarily existing in the digital space, amateur translators (bi/multilinguals without formal training) are slowly taking over given they provide services at lower prices, professional translators battle high productivity pressure, market demands are challenging due to the competitiveness of the market itself, freelancers have to deal with their (quite 
often unsettled) status and technologization is extremely fast (2019). That is why it seems necessary to establish new directions in both research and practice which would enable a better synergy between scholars, practitioners and the industry (DAM \& KOSKINEN 2016). The digital space seems to be the perfect venue for such a synergy; therefore, it could be used to enhance the possibilities of interdisciplinary directions within TS.

\section{Conclusion}

It is obvious that translation is now exceeding the scopes of the traditional translation of literary and non-literary texts. The rapid development of the Internet and information communication technology in its broadest sense have brought about content and discourse which needs new approaches.

The implications that these new contents bring about are challenging and they are related to the three areas elaborated in this paper, i.e. theoretical research, the training of translators and the professional practice of translation. In addition, the scopes of technology need to be re-evaluated and redefined. Again the traditional understanding of machine translation, which is mainly seen as related to translation software and CAT tools (e.g. Trados, Accross, etc.) have to be reviewed so as to explore their possibilities in relationship to more specific multimodal and multimedia content as well as to analytical tools which should enable adequate approaches to translation products from fields and areas yet to appear.

To conclude, given the fascinating possibilities technology and the digital space will undoubtedly provide us with in the future, it may be expected that both theoretical and practical explorations within TS will take many new interdisciplinary directions in the future. And they will all have to be explored both by scholars and practitioners.

\section{Works Cited}

BAKER \& SALDANHA, 2009: BAKER, Mona, and Gabriela SALDANHA. Routledge Encyclopedia of Translation Studies. London and New York: Routledge, 2009. BASSNETT 2013: BASSNETT, Susan. Translation. London and New York: Routledge, 2013.

BATEMAN, WILDFEUER et al. 2017: BATEMAN, John A., Janina WILDFEUER, and Tuomo HIIPPALA. Multimodality: Foundations, Research and Analysis. A Problem-Oriented Introduction. Berlin: De Gruyter, 2017.

BORIA, CARRERES et al. 2020: BORIA, Monica, Ángeles CARRERES, María NORIEGA-SÁNCHEZ, and Marcus TOMALIN. Translation and Multimodality, Beyond Words. London: Routledge, 2020.

CARR 2011: CARR, Nicholas. The Shallows: What the Internet is Doing to Our Brains. New York City: W. W. Norton \& Company, 2011. 
CRONIN 2010: CRONIN, Michael. “The Translation Crowd.” Revista Tradumàtica: tecnologies de la traducció, vol. 8 (2010): 1-7.

DENNIS \& URRY 2007: DENNIS, Kingsley, and John URRY. “The Digital Axis of Post-Automobility." Department of Sociology, Lancaster University (2007): $1-74$.

DÍAZ-CINTAS \& MUÑOS SÁNCHEZ 2006: DÍAZ-CINTAS, Jorge, and Pablo MUÑOS SÁNCHEZ. "Fansubs: Audiovisual Translation in an Amateur Environment.” The Journal of Specialised Translation, vol. 6 (2006): 37-52.

DOHERTY 2016: DOHERTY, Stephen. “The Impact of Translation Technologies on the Process and Product of Translation." International Journal of Communication, vol. 10 (2016): 947-969.

DAM \& KOSKINEN 2016: DAM, Helle Vrønning, and Kaisa KOSKINEN. “The Translation Profession: Centres and Peripheries: Introduction”. Journal of Specialised Translation, vol. 25 (2016): 2-14.

ELIA 2019: ELIA. "European Language Industry Survey." < http://elia-association.org/ our-events/> 4 July 2020.

FELDMAN 2005: FELDMAN, Tony. An Introduction to Digital Media. New York: Routledge, 2005.

FLEW 2008: FLEW, Terry. New Media: An Introduction. 3rd edition. Oxford and New York: Oxford University Press, 2008.

GAMBIER 2016: GAMBIER, Yves. "Rapid and Radical Changes in Translation and Translation Studies." International Journal of Communications, vol. 10 (2016): 887-906.

HAYLES 2010: HAYLES, N. Katherine. “How We Read: Close, Hyper, Machine.” ADE bulletin, vol. 150, issue 18 (2010): 62-79.

HENRY 2019: HENRY, Jones. "Wikipedia as a Translation Zone: A Heterotopic Analysis of the Online Encyclopedia and Its Collaborative Volunteer Translator Community." Target, vol. 31, issue 1 (2019): 77-97.

HEJWOWSKI 2004: HEJWOWSKI, Krzysztof. Translation: A Cognitive-Communicative Approach. Olecko: Wydawnictwo Wszechnicy Mazurskiej, 2004.

HOLMES 1988: HOLMES, James. Translated! Papers on Literary Translation and Translation Studies. Amsterdam: Rodopi, 1988.

JENKINS 2006: JENKINS, Henry. Fans, Bloggers, and Gamers: Exploring Participatory Culture. New York and London: New York University Press, 2006.

JIMÉNEZ-CRESPO 2013: JIMÉNEZ-CRESPO, Miguel Angel. Translation and Web Localization. New York: Routledge, 2013.

JIMÉNEZ-CRESPO 2017: JIMÉNEZ-CRESPO, Miguel Angel. Crowdsourcing and Online Collaborative Translations: Expanding the Limits of Translation Studies. Amsterdam/Philadelphia: John Benjamins, 2017.

KATAN 2014: KATAN, David. Translating Cultures: An Introduction for Translators, Interpreters and Mediators. London and New York: Routledge, 2014.

KUSHNER 2013: KUSHNER, Scott. “The Freelance Translation Machine: Algorithmic Culture and the Invisible Industry." New Media \& Society, vol. 15, issue 8 (2013): 1241-1258.

MATSUDA \& SILVA 2014: MATSUDA, Paul Kei, and Tony SILVA. Second Language 
Writing Research: Perspectives on the Process of Knowledge Construction. New Jersey: Lawrence Erlbaum Associates, 2014.

MOORKENS 2016: MOORKENS, Joss. "Under Pressure: Translation in Times of Austerity." Perspectives: Studies in Translation Theory and Practice, vol. 25, issue 3 (2016): 464-477.

MUNDAY \& ZHANG 2017: MUNDAY, Jeremy, and Meifang ZHANG. Discourse Analysis in Translation Studies. John Benjamins, 2017.

O’HAGAN 2009: O’HAGAN, Minako. "Evolution of User-Generated Translation: Fansubs, Translation Hacking and Crowdsourcing." The Journal of Internationalization and Localization, vol. 1 (2009): 94-121.

O’HAGAN 2011: O’HAGAN, Minako. “Community Translation: Translation as a Social Activity and Its Possible Consequences in the Advent of Web 2.0 and beyond." Linguistica Antwerpiensia New Series - Themes in Translation Studies, vol. 10 (2011): 11-23.

O’HAGAN 2015: O’HAGAN, Minako. “Game Localisation as Software-Mediated Cultural Experience: Shedding Light on the Changing Role of Translation in Intercultural Communication in the Digital Age." Multilingua, vol. 34, issue 6 (2015): 747-771.

O’HAGAN 2017: O’HAGAN, Minako. “Deconstructing Translation Crowdsourcing with the Case of a Facebook Initiative: A Translation Network of Engineered Autonomy and Trust?" In: Kenny, Dorothy, ed. (2017), Human Issues in Translation Technology. London and New York: Routledge, 25-44.

OŽBOT 2015: OŽBOT, Marina. “Translation Studies - Interdisciplinary, Multidisciplinary or Transdisciplinary?” Meta, vol. 60, issue 2 (2015), 360-360.

PORRAS \& CASSANY 2017: PORRAS, María José Valero, and Daniel CASSANY. "Translation by Fans for Fans: Organization and Practices in a Spanish-Language Community of Scanlation." BiD: textos universitaris de biblioteconomia i documentació, vol. 37 (2017).

RHEINGOLD 1993: RHEINGOLD, Howard. The Virtual Community: Homesteading on the Electronic Frontier. Reading, Mass.: Addison-Wesley, 1993.

ROBINSON 2017: ROBINSON, Douglas. Critical Translation Studies. Routledge Advances in Translation and Interpreting Studies. Taylor \& Francis, 2017.

ROJO 2015: ROJO, Ana. “Translation Meets Cognitive Science. The Imprint of Translation on Cognitive Processing." Multilingua: Journal of Cross-Cultural and Interlanguage Communication, vol. 34, issue 6 (2015): 721-746.

ROSMAN \& RUBEL 2003: ROSMAN, Abraham, and Paula G. RUBEL. Translating Cultures. Perspectives on Translation and Anthropology. Oxford: Berg Publishers, 2003.

SAURO 2017: SAURO, Shannon. "Online Fan Practices and CALL." CALICO Journal, vol. 34, issue 2 (2017), 131-146.

SCHÄFFNER 2019: SCHÄFFNER, Christina. “Translation and Discourse Analysis.” Slovo.ru: baltic accent, vol. 10, issue 3 (2019): 28-42.

SHARIFIAN 2017: SHARIFIAN, Farzad. Cultural linguistics. Amsterdam: John Benjamins Publishing, 2017.

SNELL-HORNBY 2006: SNELL-HORNBY, Mary. The Turns of Translation Studies: 
New paradigms or shifting viewpoints? Vol. 66. Amsterdam: John Benjamins, 2006.

ŠVELCH 2013: ŠVELCH, Jaroslav. “The Delicate Art of Criticizing a Saviour: 'Silent Gratitude' and the Limits of Participation in the Evaluation of Fan Translation." Convergence, vol. 19, issue 3 (2013): 303-310.

TAPSCOTT \& WILLIAMS 2006: TAPSCOTT, Don, and Anthony WILLIAMS. Wikinomics: How Mass Collaboration Changes Everything. New York: Portfolio, 2006.

TENNENT 2005: TENNENT, Martha. Training for the New Millennium: Pedagogies for Translation and Interpreting, Vol. 60. Amsterdam: John Benjamins Publishing, 2005.

TOURY 2012: TOURY, Gideon. Descriptive Translation Studies and beyond, Revised Edition, Vol. 100. Amsterdam: John Benjamins, 2012.

WELLMAN 2018: WELLMAN, Berry. Networks in the Global Village: Life in Contemporary Communities. New York: Routledge, 2018. 
Jasmina Đorđević

\section{COMMUNITY I FAN TRANSLATION: POTENCIJALI ZA NOVE PRAVCE U NAUCI O PREVOĐENJU U DIGITALNOM PROSTORU}

Cilj ovog rada je da predstavi dva relativno nova trenda u nauci o prevođenju u digitalnom prostoru i da se osvrne na pojedine interdisciplinarne implikacije koje bi novi pravci mogli da imaju u nauci o prevođenju u budućnosti. Ne samo da digitalni prostor obezbeđuje nove alate i tehnologije, već omogućava i proučavanje fenomena i primena koje izlaze iz okvira postojećih interdisciplinarnih veza koje je nauka o prevođenju do sada uspostavila. U ovom radu ćemo predstaviti dva relativno nova trenda, community translation (srp. prevođenje u zajednicama) i fan translation (srp. prevod obožavalaca), sa ciljem da ukažemo na neophodnost da se ova dva oblika prevođenja dublje istražuju, jer mogu biti od koristi za sve učesnike u prevođenju, tj. istraživače, prevodioce, studente prevođenja i predstavnike u industriji prevođenja u celosti. Zaključni prikaz potencijalnih implikacija novih interdisciplinarnih pravaca bi mogao da motiviše teorijska istraživanja u okviru nauke o prevođenju u digitalnom prostoru kojima, tako se čini, do sada nije posvećeno dovoljno pažnje. Ishod bi bio da se otvore vrata primeni dva pomenuta trenda u prevođenju u kontekstu koji izlazi iz okvira industrije zabave i razonode gde se ova dva oblika prevođenja trenutno mogu naći.

Ključne reči: Nauka o prevođenju, digitalni prostor, community i fan translation, interdisciplinarnost, implikacije 